\title{
Biscutum constans coccolith size patterns across the mid Cretaceous in the western Tethys: Paleoecological implications
}

\author{
Cinzia Bottini *, Giulia Faucher \\ Department of Earth Sciences, Università degli Studi di Milano, 20133 Milan, Italy
}

\section{ART ICLE IN FO}

\section{Keywords}

Morphometry

Coccoliths

Nannofossil

Adaptation

Mid Cretaceous

\begin{abstract}
A B S T R A C T
The morphometric record of the calcareous nannofossil species Biscutum constans from the western Tethys indicates that this species underwent marked size changes across the latest Barremian-Cenomanian interval $(\sim 28$ Myrs). Significant size reduction occurred during the core of the early Aptian Oceanic Anoxic Event (OAE) 1a $(\sim 120 \mathrm{Ma})$ and soon after OAE $1 \mathrm{a}$ followed by a 9 Myr-long interval characterized by small specimens. Larger coccoliths marked the middle to late Albian and, particularly, the lower part of the nannofossil subzone NC10a was characterized by abundant large specimens. A minor size decrease coincided with the late Albian OAE $1 \mathrm{~d}$ onset $(\sim 100 \mathrm{Ma})$, but very small size was reached again during the latest Cenomanian OAE $2(\sim 94.4 \mathrm{Ma})$. The sequence of relatively long (millions of years) intervals marked by different average sizes is interpreted to reflect adaptation to changing paleoecological conditions. Temperature and fertility were not directly influencing the size of $B$. constans. On shorter time scale, abrupt changes in ocean chemistry related to Large Igneous Provinces submarine volcanism played a central role in secretion of small B. constans coccoliths to face ocean acidification during OAE 1a and OAE 2. Contrarily, during the late early Aptian-early Albian time interval, smaller $B$. constans size was related to cooler temperature which possibly also promoted $\mathrm{CO}_{2}$ sequestration in cooler surface waters forcing $B$. constans to produce small coccoliths to survive lowered $\mathrm{pH}$. In addition, pulses of subaerial volcanism of the Southern Kerguelen Plateau may have further affected the ocean chemistry. The termination of intense volcanism and warmer temperature in the middle Albian-early Cenomanian coincided with restoration of bigger B. constans specimens.
\end{abstract}

\section{Introduction}

Coccoliths are the calcitic remains of coccolithophore exoskeleton called coccosphere. Coccolithophorids are phytoplanktonic algae which are widespread in the oceans and important rock-forming organisms since the Jurassic (e.g., Bown et al., 2004; Erba, 2006). Due to their sensitivity to oceanic physical and chemical parameters, fossil coccoliths and nannoliths have been used, since the seventies (Roth, 1979, 1987, 1989; Roth and Bowdler, 1981; Roth and Krumbach, 1986), as proxy in Mesozoic paleoceanography.

During the last decades, numerous works focused on coccolith and nannolith size variations to verify a possible link between size and paleoenvironmental changes and implement their use as paleoceanographic tracers (e.g., Mattioli et al., 2004; Bornemann and Mutterlose, 2006; Mattioli et al., 2009; Erba et al., 2010; Linnert and Mutterlose, 2012; Barbarin et al., 2012; Lübke et al., 2015; Lübke and Mutterlose, 2016; Peti and Thibault, 2017; Faucher et al., 2017a; Ferreira et al., 2017; Erba et al., 2019;
Gollain et al., 2019). Some of these morphometric studies included measurements of Biscutum constans (Górka, 1957) Black, 1967, which is a placolith with a broad rim and a narrow and empty central area. Bicuscutm constans was a relatively common species in the Cretaceous and it has been interpreted to prefer mesotrophic conditions (Roth and Krumbach, 1986; Premoli Silva et al., 1989a, 1989b; Watkins, 1989; Coccioni et al., 1992; Erba et al., 1992; Williams and Bralower, 1995; Bellanca et al., 1996; Herrle, 2003; Herrle et al., 2003; Bornemann et al., 2005; Mutterlose et al., 2005; Tremolada et al., 2006; Tiraboschi et al., 2009). This species underwent size variations during the Valanginian Weissert-Oceanic Anoxic Event (OAE) (Möller et al., 2020), the Barremian Hauptblätterton (Wulff et al., 2020), the early Aptian OAE 1a (Erba et al., 2010; Lübke and Mutterlose, 2016), the latest Albian OAE 1d (Bornemann and Mutterlose, 2006) and latest Cenomanian OAE 2 (Linnert and Mutterlose, 2012; Faucher et al., 2017a). Altered carbonate chemistry and $\mathrm{CO}_{2}$-induced ocean acidification (OA; Erba et al., 2010; Faucher et al., 2017a), tem-

* Corresponding author.

E-mail addresses: cinzia.bottini@unimi.it (C. Bottini); giulia.faucher@unimi.it (G. Faucher) 
perature changes (Bornemann and Mutterlose, 2006; Wulff et al., 2020), variation in light availability (Lübke and Mutterlose, 2016), altered surface water nutrient content (Linnert and Mutterlose, 2012; Möller et al., 2020; Wulff et al., 2020) and excess trace metal concentrations (Faucher et al., 2017a) were addressed as possible causes of $B$. constans size reduction over these intervals. So far, none of the interpretation proposed has been totally excluded and the causes of $B$. constans size variations are still under debate.

Most morphometric studies focused on OAEs since they are ideal to understand the response of coccolithophores to "extreme" environmental conditions. As a consequence, little is known about the size variations through intervals not associated with OAEs and proper long-term record of nannofossil morphometrics is missing.

In this work, we investigated $B$. constans size evolution through a 28 my-long interval, from the latest Barremian to the Cenomanian, which includes global OAEs and long interludes without OAEs. We focused on the Umbria-Marche Basin (Piobbico core and Monte Petrano section) which provides a continuous record through the mid Cretaceous and allows a comparison of the morphometric data with available paleoceanographic and paleoclimatic reconstructions performed on the same sections (Bottini et al., 2015; Bottini and Erba, 2018). The dataset was integrated with size measurements for the latest Barremian-early Aptian from Erba et al. (2010).

The objectives of this study are to: 1) quantify size variations of $B$. constans during the latest Barremian-Cenomanian interval; 2) identify if $B$. constans size variations also occurred during intervals not marked by OAEs; 3 ) detect if changes in the size of $B$. constans reflect an evolutionary trend or a response to long-term environmental changes; 4 ) test if $B$. constans size variations were induced by changes in climatic conditions and/or surface water fertility conditions.

\section{Studied sections}

We studied the Aptian - upper Cenomanian in the Umbria-Marche succession of the Central Apennines belt (central Italy) (Fig. 1). The sequence consists of pelagic to hemipelagic sediments deposited at subtropical latitudes (Alvarez and Lowrie, 1984) in the Western Tethys on the continental crust of the Adria microplate (Rosenbaum et al., 2004) at estimated paleodepth of ca. 1500-2000 m (Bernoulli, 1972; Bernoulli and Jenkyns, 1974, 2009). The studied sequence includes the Marne a Fucoidi Formation (lower Aptian - upper Albian) which consists of a rhythmic sequence of marlstone, marly limestone, marly claystone and black shale (Herbert and Fischer, 1986; Erba et al., 1989; Fisher et al., 1991; Erba and Premoli Silva, 1994; Herbert et al., 1995; Fiet et al., 2001; Grippo et al., 2004) and the Scaglia Bianca Formation (upper Albian - upper Cenomanian) (Coccioni and Galeotti, 2003) that consists of alternated limestones/marly limestones and radiolarian layers/chert bands (Gambacorta et al., 2015, 2016).

We investigated two sedimentary successions of the Umbria Marche Basin (described below): the Piobbico core and the Monte Petrano section. The data collected were integrated with the morphometric data from the Cismon core (Belluno Basin, Italy) studied by Erba et al. (2010) spanning the latest Barremian - early Aptian (Fig. 1). Two samples from the Cismon core $\left(46^{\circ} 02^{\prime} 00^{\prime \prime} \mathrm{N} / 11^{\circ} 45^{\prime} 00^{\prime \prime} \mathrm{E}\right)$ were additionally studied above the Selli Level at the top of calcareous nannofossil Zone NC6 (Fig. 2).

The Piobbico core was drilled at "Le Brecce" $\left(43^{\circ} 35^{\prime} 3.78^{\prime \prime} \mathrm{N} /\right.$ $12^{\circ} 29^{\prime} 10.09^{\prime \prime}$ E) located $3 \mathrm{~km}$ west of the town of Piobbico at $\mathrm{Km} 33$ of the Apecchiese State Road No. 257 (Fig. 2). The core includes the Selli Level (OAE 1a), although it is not complete since a disconformity eliminates its basal part (Bottini et al., 2015), the 113 Level and the Kilian Level represented by centimetric black shales levels,

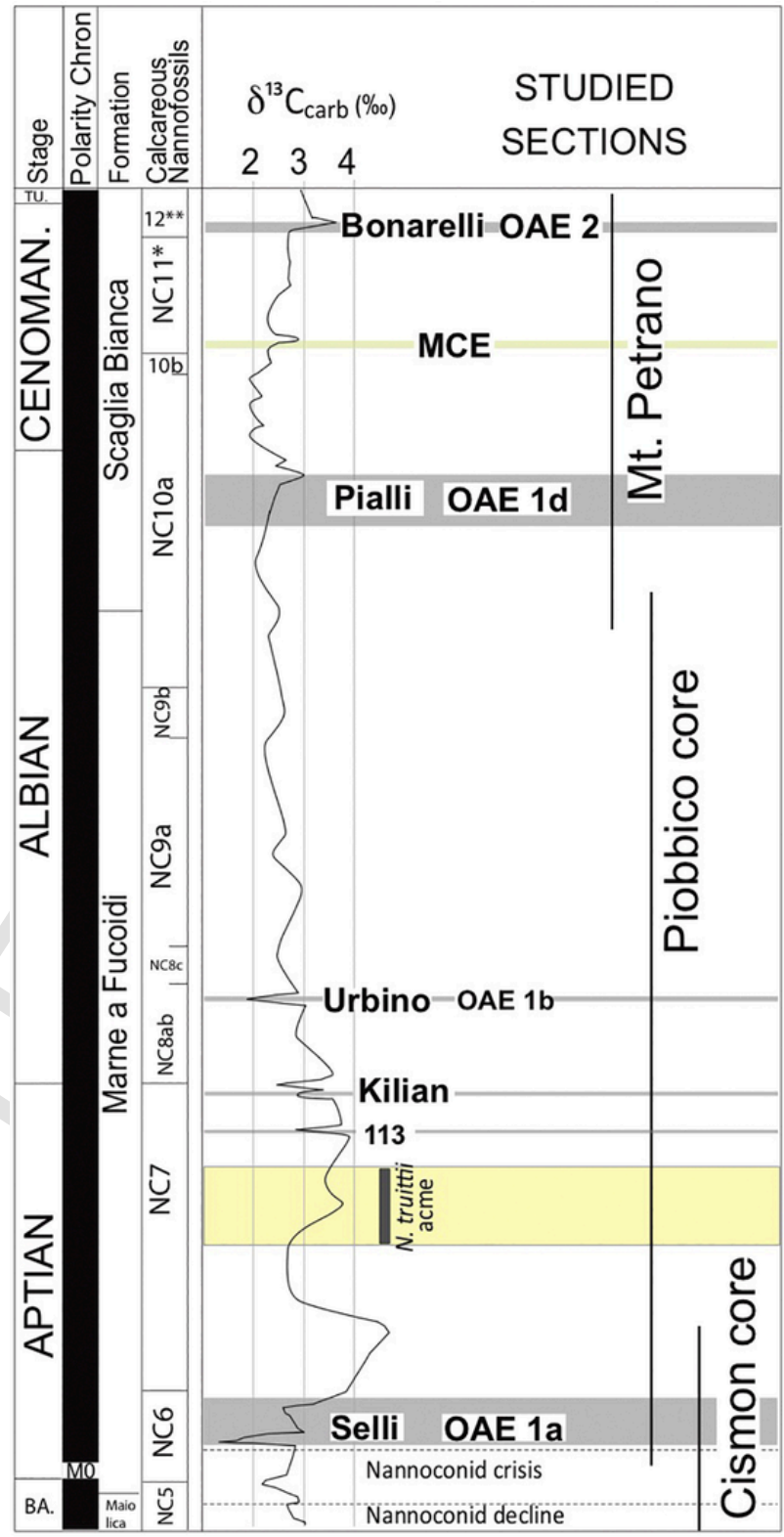

Fig. 1. Stratigraphic range of the studied sections plotted against the late Barremian early Turonian chronostratigraphic framework from Bottini and Erba (2018). Nannofossil zones are after Bralower et al. (1995).

and the Urbino Level (OAE 1b) ca. $27 \mathrm{~cm}$ thick. The stratigraphic thickness equals $77 \mathrm{~m}$ and the studied interval goes from 71 to $8.5 \mathrm{~m}$ extending from the base of nannofossil Zone NC7 to the top of Zone NC9.

The Monte Petrano section ( $43^{\circ} 30^{\prime} 16.14^{\prime \prime} \mathrm{N} / 12^{\circ} 36^{\prime} 50.94^{\prime \prime}$ E) covers $80.5 \mathrm{~m}$ and it is located close to the village of Moria and includes black shale layers of the Pialli Level which are restricted to the lower part of the OAE 1d carbon-isotope excursion (Schwarzacher, 1994; Giorgioni et al., 2012; Gambacorta et al., 2014, Figs. 1, 2). The Mid Cenomanian Event (MCE) I coincides with a lithological shift to organic-rich black shales and black chert bands alternated with whitish limestones. The $\delta^{13} \mathrm{C}$ positive anomaly of OAE 2 (at Monte Petrano and Furlo) is associated with the organic-rich and carbonate-lean Bonarelli Level, but only the first part of the OAE 2 carbon isotope excursion is preserved since a hiatus at the top of the Bonarelli Level elides most of the "plateau", the "c" peak and the first part of the decrease (Gambacorta et al., 


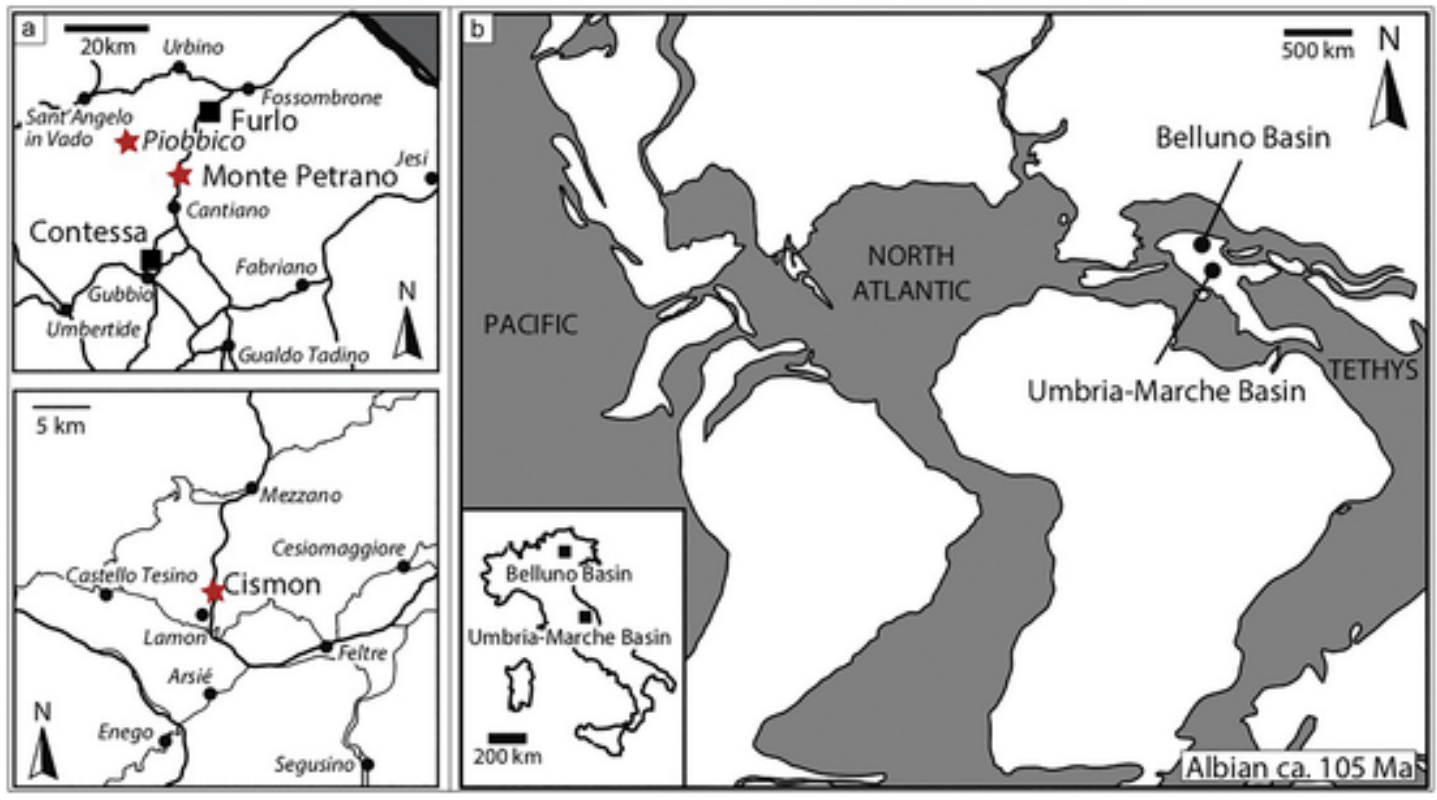

Fig. 2. (a) Present-day and (b) paleogeographic location (at ca. $105 \mathrm{Ma}$ ) of the studied sections, modified from Gambacorta et al. (2015).

2015). The section was studied in the interval comprised between the base of Zone NC10 to the top of Zone NC11*. The OAE 2 was not studied since it is barren of nannofossils.

We adopt the composite section from the uppermost Barremian to the top of the Cenomanian built in Bottini and Erba (2018) which includes the Cismon core, the Piobbico core and Monte Petrano section. Sampling was conducted in order to gain a constant resolution of ca. 200 kyrs (following the time scale of Malinverno et al. $(2010,2012)$ and the cyclostratigraphy of Gambacorta et al. (2018). In the interval corresponding to nannofossil Zone NC7 and NC8a the sampling resolution is lower since some samples were devoid of B. constans (Bottini et al., 2015).

\section{Methods}

\subsection{Sample preparation}

A total of 53 samples were studied in the Piobbico core, 30 samples in the Monte Petrano section and 2 in the Cismon core. Calcareous nannofossils were investigated in smear slides under light polarizing microscope at $1250 \times$ magnification. Smear slides were prepared using standard techniques (Bown and Young, 1998): a small fraction of sediment was powered with bidistillate water; a few drops of the suspension were spread over a slide, leaving to dry and sealed on a glass slide with Norland Optical adhesive.

\subsection{Morphometrics}

Morphometric analyses on $B$. constans were performed under polarized light microscope. Pictures of 30 specimens for each studied sample were captured with a Q-imaging Micro publisher 5.0 RTV camera mounted on a Leitz Laborlux light microscope. The software used to take the pictures was Q-capture Pro suite. Measurements were taken using ImageJ64 software. The error of measurements is $\pm 0.08 \mu \mathrm{m}$. In 5 samples we measured less than 30 specimens due to the low abundance of this species. The total number of specimens measured is provided in Supplementary Table S1.

The identification of B. constans (Górka, 1957) Black, 1967 follows the original description and no distinction is made for B. ellipticum (Górka, 1957) Grün and Allemann, 1975 since it is consid- ered a synonym of $B$. constans (see Bornemann and Mutterlose, 2006; Brace and Watkins, 2014).

The nannofossil preservation was assessed under light polarizing microscope to ascertain the degree of etching and/or overgrowth. Diagenetically altered specimens were discarded since partial dissolution or overgrowth may decrease or enlarge the coccolith size, respectively. Only complete specimens of $B$. constans with continuous outline were selected.

For each specimen length and width of the total coccolith was measured. This resulted in a total of 2505 measurements performed. According to previous studies the measurement of at least 30 specimens for each given species per sample provides a sufficient reproducibility for the mean and the 95\% confidence limit (e.g., Erba et al., 2010; Faucher et al., 2017a). We also calculated the coccolith ellipticity (length/width ratio).

\subsection{Statistics}

Data were statistically analysed to obtain mean, median, maximum and minimum values, 95\% confidence intervals and standard deviation (sdt. Dev.) and the linear regression function between length and width (Supplementary Table S1). A mixture analysis was run on length and width, using PAST software (Hammer et al., 2001), in order to find the overall mixing proportions of specimens and verify the eventual occurrence of different taxa (Fig. 3). $t$-tests were performed with R software in order to determine if there are significant differences between B. constans sizes among the established intervals. Statistical significance was accepted for $p<.05$.

We performed regression analyses to estimate the relationship between $B$. constans size and $B$. constans abundance, Nutrient Index (NI) and Temperature Index (TI). The analyses were performed using the data of the matching samples for all the 4 variables, (size, abundance, $\mathrm{NI}$ and TI). Biscutum constans relative abundance and nannofossil TI and NI are from Bottini et al. (2015) and Bottini and Erba (2018). Relative abundances were obtained in smear slides counting, under polarizing light microscope at $1250 \times$ magnification, at least 300 specimens and are expressed in percentages. The NI includes higher-fertility (Biscutum constans, Zeugrhabdotus erectus, Discorhabdus rotatorius) and lower fertility (Watznaueria barnesiae) nannofossil taxa. The TI is based on warmer-temperature (Rhagodis- 

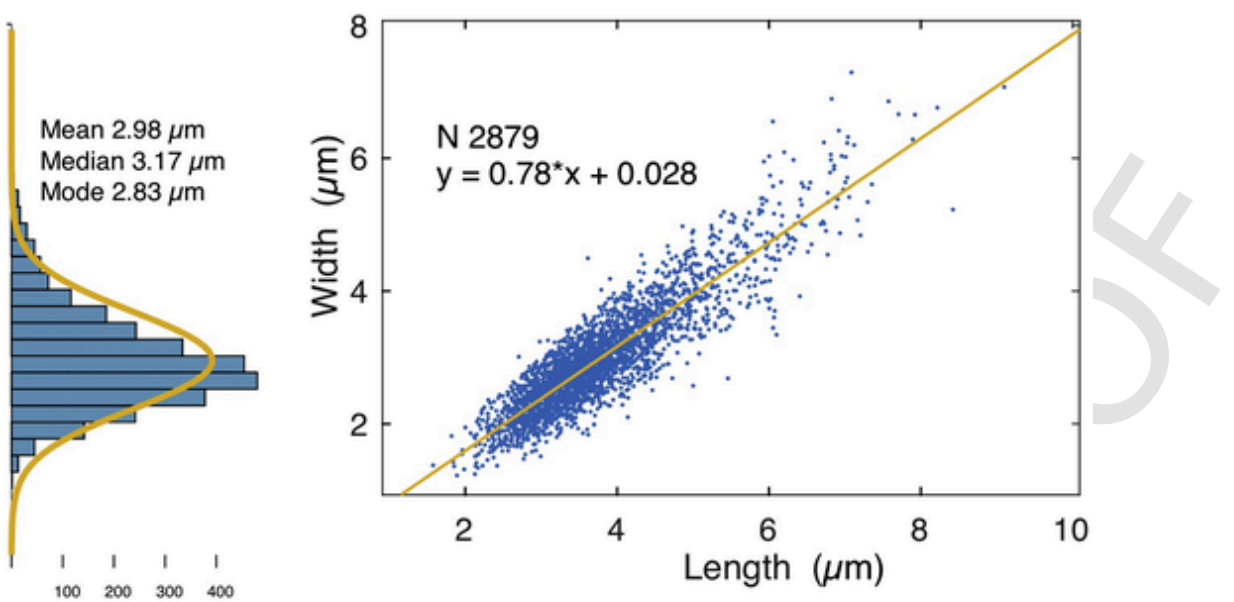

Frequency $(\mathrm{n})$

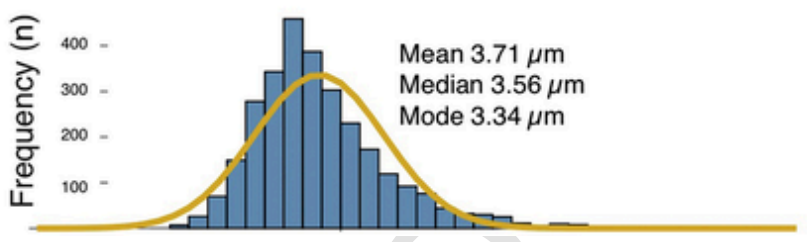

Fig. 3. Scatter plots and frequency histograms of all Biscutum constans length and width measurements. The linear regression, the mean, median and mode are given.

cus asper, Zeugrhabdotus diplogrammus) and cooler-temperature (Staurolithites stradneri, Eprolithus floralis, Repagulum parvidentatum) taxa. For further information see Bottini et al. (2015) and Bottini and Erba (2018). The values of $B$. constans abundance, NI and TI used for the regression analyses are reported in Supplementary Table S2 and the results of the statistical analyses are indicated in Supplementary Table S3.

\section{Results}

\subsection{Calcareous nannofossil preservation}

In the studied sections, calcareous nannofossil preservation is moderate, dissolution-prone species (e.g., B. constans, Z. erectus, D. rotatorius) are relatively abundant (Tiraboschi et al., 2009; Bottini et al., 2015; Bottini and Erba, 2018) and minor indications of etching and overgrowth were sporadically detected (Fig. 4). Our estimates agree with evaluation of dissolution and overgrowth previously published for nannofossil assemblages of the Piobbico core (Erba, 1988, 1992; Tiraboschi et al., 2009; Bottini et al., 2015) and Monte Petrano (Gambacorta et al., 2015; Bottini and Erba, 2018). We therefore consider that the size variations detected in this study reflect a biological response rather than depending on dissolution effects.

\subsection{Biscutum constans size variations}

Biscutum constans length is linearly correlated with the width $\left(\mathrm{R}^{2}=0.77\right.$, Fig. 3). A similar relationship was identified in other studies dealing with $B$. constans size measurements (e.g., Bornemann and Mutterlose, 2006; Linnert and Mutterlose, 2012; Lübke et al., 2015; Faucher et al., 2017a; Möller et al., 2020), consequently, in this work we only describe and comment on variations in length.

Size fluctuations of $B$. constans through the latest Barremian - latest Cenomanian time interval are presented in the composite section (from Bottini and Erba, 2018) which includes the data from the Cismon core, the Piobbico core and Monte Petrano section (Fig. 5). The lowermost 12 samples of the Cismon core are from Erba et al.
(2010), the two samples in the topmost part of the core are from this work.

Every measured and calculated statistical parameter (mean length and width, maximum and minimum length and width, sdt. dev, and ellipticity) of $B$. constans is available in the supporting information in Supplementary Table S1. The length of B. constans ranges from 1.58 to $7.30 \mu \mathrm{m}$. A mean of $3.71 \mu \mathrm{m}$ is estimated for the overall studied population (Fig. 5, Supplementary Table S1). The coccolith length is unimodally distributed and the frequency histograms (Fig. 3 and Supplementary Fig. S1) exhibit a positive skewness of coccolith sizes.

The average values of $B$. constans length (mean and median) show size variations throughout the sites that can be described in seven distinct intervals (Figs. 5 and 6; Table 1). Intervals 1 to 3 were identified by Erba et al. (2010) using the same criterium adopted here to define intervals 4 to 7: each interval includes a group of samples, in stratigraphical order, with significantly different $(p<.05)$ median length values (lower or higher) from those of the samples of the interval stratigraphically below and above. This is revealed also in Fig. 6 where the seven box plots relative to the seven intervals, describe the dispersion of the measured specimens and evidence the fluctuations in sizes through time.

The seven intervals are described as follows: interval 1 goes from just prior to the nannoconid decline up to the nannoconid crisis which precedes the OAE 1a onset and is characterized by larger specimens (average length $=5.22 \mu \mathrm{m}$ std. 1.15 ); interval 2 corresponds to the negative carbon isotope excursion of OAE $1 \mathrm{a}$ and coincides with $B$. constans size reduction of ca. $35 \%$ (average length $=3.88 \mu \mathrm{m}$, sdt. 0.85 ) compared to interval 1 ; interval 3 corresponds to the middle and late part of OAE 1a and it is characterized by bigger $B$. constans coccoliths (average length $=4.80 \mu \mathrm{m}$, sdt. 0.89 ) compared to interval 2 ; interval 4 extends from the end of OAE 1 a to the middle of nannofossil subzone NC8c in the early Albian and displays the lowest average B. constans length (average length $=3.13 \mu \mathrm{m}$, sdt. 0.49); interval 5 extends from the middle of nannofossil subzone NC8c up to the base of nannofossil subzone NC9b and it is marked by average $B$. constans length which is closer to the total mean size of the studied interval (average 

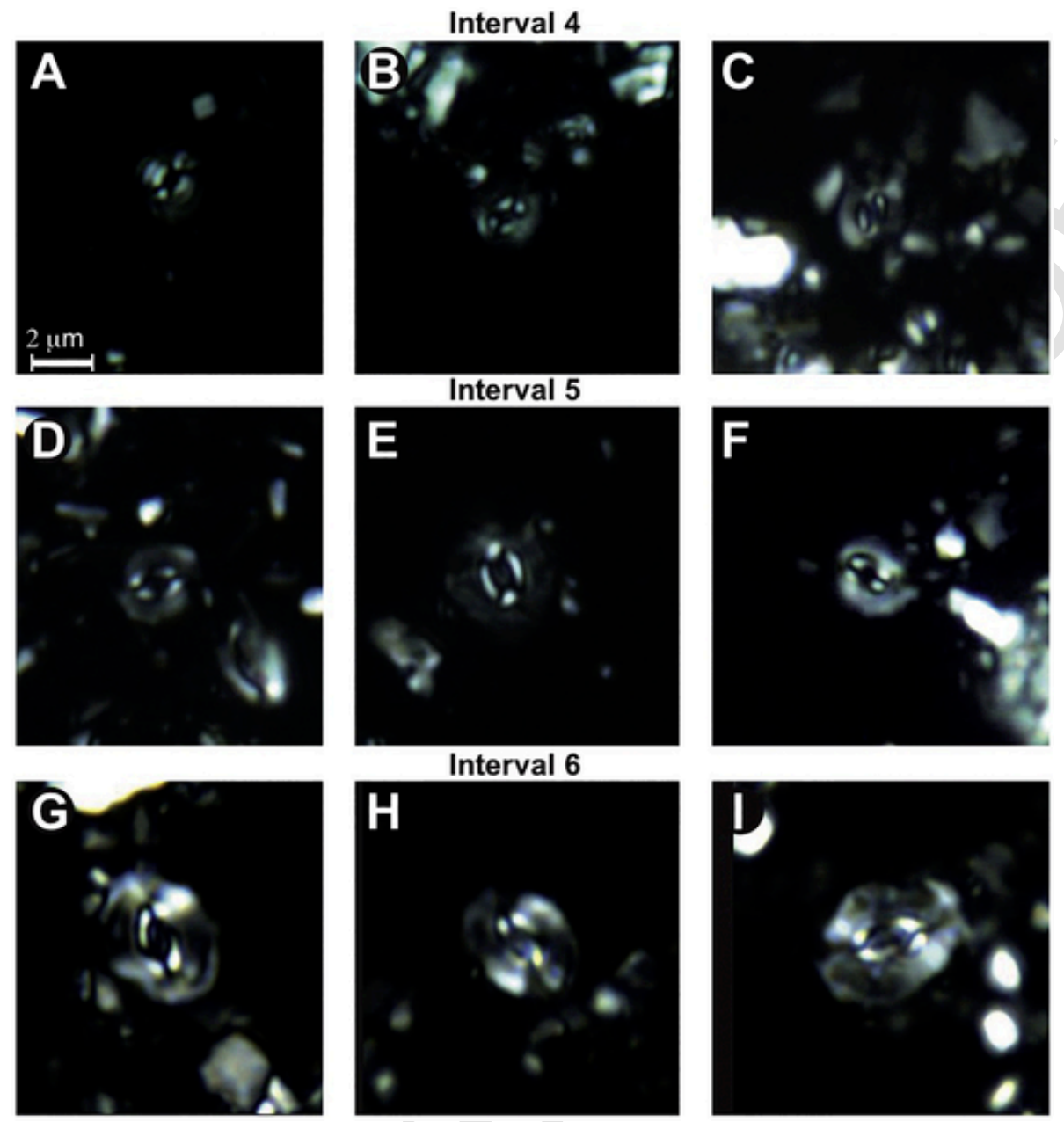

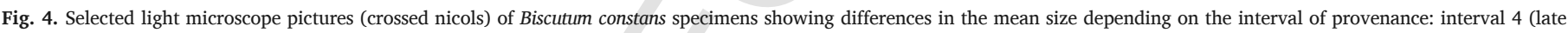
Aptian-early Albian), interval 5 (middle Albian) and interval 6 (late Albian). Scale bar is $2 \mu \mathrm{m}$.

length $=3.68 \mu \mathrm{m}$; sdt. 0.66); interval 6 goes from the base of nannofossil subzone NC9b to the middle of subzone NC10a and shows higher average sizes of $B$. constans (average $=4.19 \mu \mathrm{m}$ sdt. 0.74 ); interval 7 is comprised between the middle of subzone NC10a to the onset of OAE 2 and it is characterized by relatively lower - but stable - mean length (average length $=3.78 \mu \mathrm{m}$, sdt 0.56).

In Supplementary Fig. S2 we represented frequency histograms for individual samples for every interval (one sample per interval). Bins are $0.5 \mu \mathrm{m}$ and 14 classes are illustrated from 1 to $8 \mu \mathrm{m}$. The chosen histograms highlight how the population size distribution changed through time. In particular, in interval 4 and interval 7, B. constans is represented by a lower number of classes bins compared to interval 1, 2 and 6. Moreover, some size classes are absent in some intervals as for example in interval 4 specimens bigger than $4 \mu \mathrm{m}$ are not displayed and in interval 3 and 6 only bigger classes ( $>3 \mu \mathrm{m}$ ) are represented (Fig. 5; Supplementary Fig. S2). These data further highlight that $B$. constans population underwent marked size changes and that during the early late Aptian-early Albian interval, the population was confined to a restricted size range compared to rest of the studied interval.

\subsection{Biscutum constans size versus other parameters}

Calculated B. constans ellipticity of each studied specimen was correlated with size to detect any correspondence (Supplementary Fig. S3). The correlation was made for all 7 intervals identified (Fig.
5) but no correlation between $B$. constans size and ellipticity was observed.

The relative abundance of $B$. constans from the same sections studied for morphometrics (Bottini et al., 2015; Bottini and Erba, 2018) shows marked variations throughout the studied interval (Fig. 5). Biscutum constans abundance was relatively low during the latest Barremian-Aptian interval. Peaks in abundance are identified before the nannoconid decline (up to ca. 15\%), in the early phase of OAE 1a and just after the end of OAE 1a (up to ca. 8\%). The early Albian coincided with a progressive increase in $B$. constans abundance which reached average of ca. $10 \%$ sustained up to the end of OAE $1 \mathrm{~d}$ although shorter interludes of lower abundances $(<5 \%$ ) are detected in the core of nannofossil subzone NC9a, in subzone NC9b and at the onset of OAE 1d. The interval comprised between the end of OAE $1 \mathrm{~d}$ and the onset of OAE 2 was characterized by a progressive decrease in abundance of $B$. constans although peaks are identified at the end of the MCE I and in the core of Zone NC11*. The changes in abundance of B. constans are not correlated with size fluctuations as indicated by statistics (Fig. 5, Supplementary Table S2, S3).

Biscutum constans size and abundance are also not related to lithological changes (Fig. 5) since their variations occur independently from rock facies. This further implies that a primary factor other than preservation influenced the variations detected. Ultimately, no correlation between coccoliths sizes and the NI or the TI 


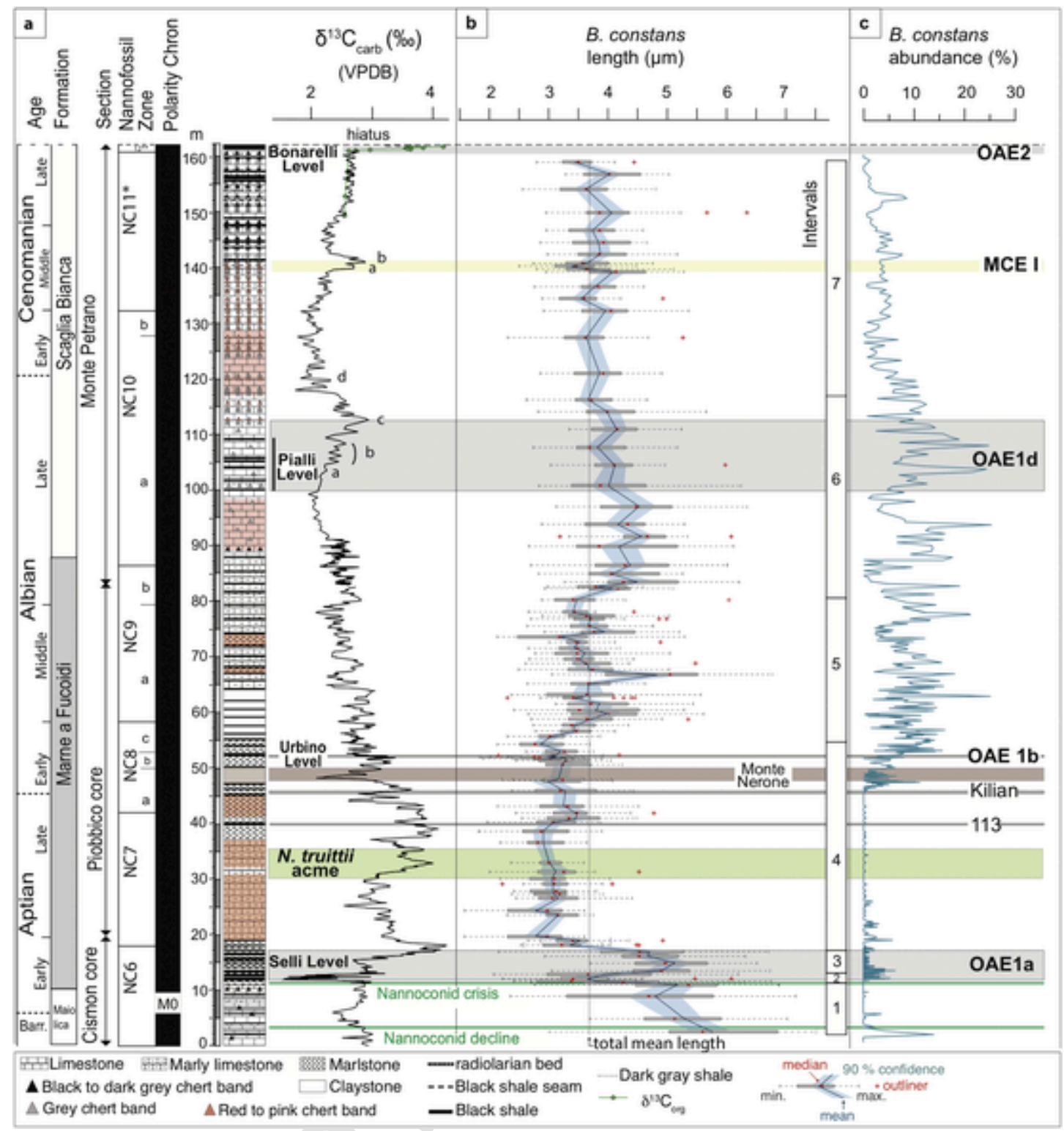

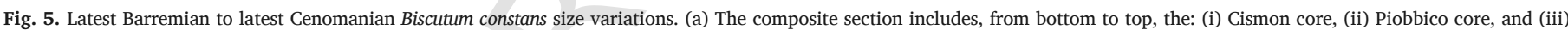

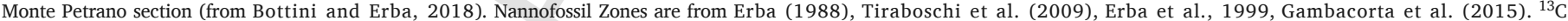

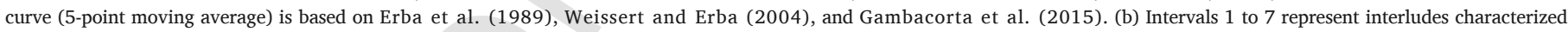

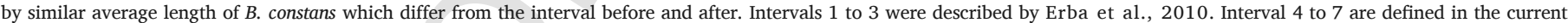

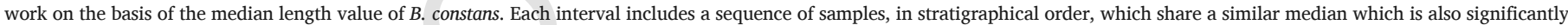

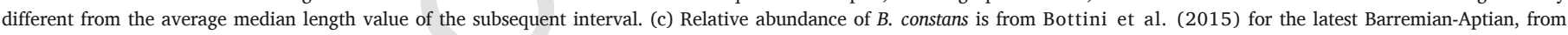
Tiraboschi et al. (2009) for the early and middle Albian and from Bottini and Erba (2018) for the late Albian-Cenomanian.

was evidenced (Supplementary Table S2 and Supplementary Table S3).

\section{Discussion}

\subsection{Long-term size variations of B. constans across the latest Barremian - Cenomanian}

The morphometric record presented in this work provides a picture of long-term size variations of $B$. constans through the latest Barremian-Cenomanian time interval and highlights seven intervals during which $B$. constans recorded fluctuations in size (Figs. 5 and 7). Intervals 1 to 3 (Figs. 5, 6 and 7) include the size changes reported by Erba et al. (2010) and highlight a significant size reduction in the core of OAE 1a (interval 2) followed by a recovery in interval 3 although pre-OAE 1a values were not reached again. Intervals 4 to 7 represent new evidence of size variations in this species. In particular, during interval $4, B$. constans was dominated by small specimens. In interval $5, B$. constans returned to values close to the total average size of the studied interval while, during interval $6, B$. constans was represented by larger specimens. In the Cenomanian (interval 7), B. constans mean size decreased again towards values around the total average size and major size decrease occurred during OAE 2 (Faucher et al., 2017a).

Before this work, morphometric studies of $B$. constans were performed only across OAE 1a (Erba et al., 2010;Lübke and Mutterlose, 2016 ), OAE 1d (Bornemann and Mutterlose, 2006) and OAE 2 (Faucher et al., 2017a), and evidenced a size reduction of $B$. constans during these Cretaceous OAEs. The novelty of the long- 


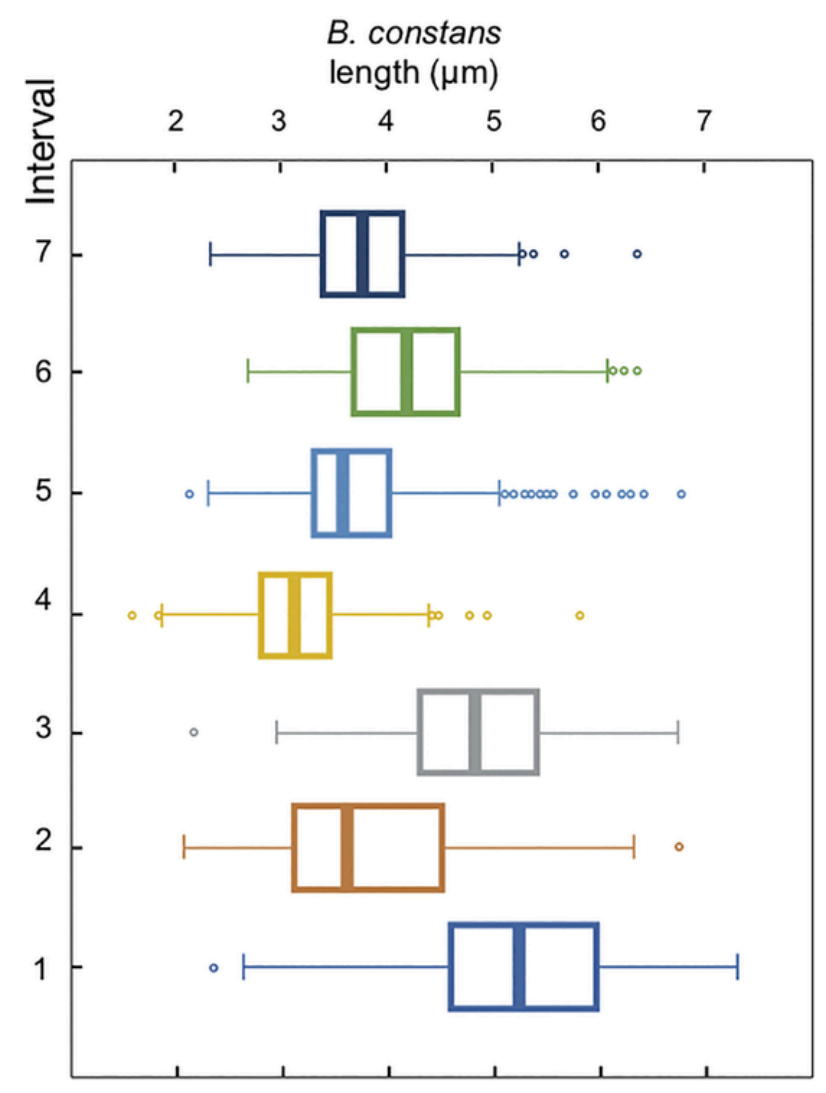

Fig. 6. Box plots of Biscutum constans length from the different intervals in stratigraphic order from bottom to top. The left and right side of each "box" are the 25th and 75th percentiles of the samples, respectively. The line in the middle of each box is the median. The whiskers, extending on the left and right of each box, represent the furthest observations. Observations beyond the whisker length are marked as outliers (circles).

term record of morphometries, is represented by the documentation of smaller B. constans (average $3.13 \mu \mathrm{m}$ ) during a prolonged time interval, ca. 9 Myrs from the late Aptian to the early Albian, not related to OAEs. Such evidence opens new questions about the environmental factor/s responsible for $B$. constans size fluctuations.

Coccolith size reductions detected during OAE 1a and OAE 2 have been proved to be of global significance (Erba et al., 2010; Lübke et al., 2015; Faucher et al., 2017a). The new morphometric record generated for the Tethys (Figs. 5 and 7), possibly suggests that the size decrease associated with OAE $1 \mathrm{~d}$ was, at least, of supra-regional extent. Although we did not investigate OAE $1 \mathrm{~d}$ in high resolution, the new data show a minor drop in $B$. constans mean size at OAE $1 d$ onset. This is similar to the $B$. constans size pattern registered in the core of OAE 1d (Main Breistroffer Level) in the Vocontian Basin (Bornemann and Mutterlose, 2006) although in the French section the average values are relatively lower (from 3.6 to ca. $3.3 \mu \mathrm{m}$ ) compared to the Tethys. If OAE 1a, OAE $1 \mathrm{~d}$ and OAE 2 were all marked by $B$. constans size decrease in the Tethys (Fig. 7), the amplitude of the variations and the minimum value reached were different for each OAE. The smallest mean size of $B$. constans was registered during OAE 2 (ca. $2.5 \mu \mathrm{m}$ ) in the Novara di Sicilia section (Faucher et al., 2017a), as the Bonarelli Level in the Umbria-Marche Basin is barren. The OAE 1a and OAE $1 \mathrm{~d}$ follow with smallest mean length of ca. $3.5 \mu \mathrm{m}$ and ca. $4 \mu \mathrm{m}$, respectively.

The size reductions associated with OAEs had a relatively short duration, corresponding to ca. 200 kyrs for OAE 1a (Erba et al., 2010) and OAE 2 (Faucher et al., 2017a) and ca. 800 kyrs for OAE 1d, based on the cyclostratigraphy of Gambacorta et al. (2018). Contrarily, during interval $4, B$. constans mean size remained relatively small for ca. 9 Myrs. So far, it is not possible to say if this size variation was registered globally because no morphometric data are available in the literature in other marine contexts for this time interval. The only evidence for B. constans size change documented in different localities refers to the equivalent to interval 6 although based on qualitative observations: the presence of common and large specimens of $B$. constans during the late Albian was reported in the Piobbico core (Erba, 1988), in south Albania (Danelian et al., 2007), in north west Germany (Čepek, 2001), and in the Shilaif Basin (United Arab Emirates; Hennhoefer et al., 2019). This evidence suggests that this interval of abundant large $(>4.19 \mu \mathrm{m}$, in the Umbria-Marche Basin) specimens of $B$. constans was not confined to the western Tethys and possibly constitutes a stratigraphic marker for the late Albian being constrained within the lower part of the nannofossil subzone NC10a (Fig. 7).

The coccolith ellipticity also varied throughout the studied interval but independently from size. Statistical analyses exclude a correlation between ellipticity and size (Supplementary Fig. S3), although qualitative observations under light microscope indicated that often larger specimens are less elliptical, and vice versa. A similar observation was made on Lotharingius sp. (Ferreira et al., 2017), while a relationship between the two parameters was documented in $B$. constans from OAE 1d (Bornemann and Mutterlose, 2006) and in other nannofossil species, such as Watznaueria barnesiae (Erba et al., 2010), Watznaueria britannica (Giraud et al., 2006), Pseudoemiliania lacunosa and Emiliania huxleyi (Young, 1989; Henderiks, 2008). Conversely, during OAE 2 the correlation was absent (Faucher et al., 2017a). The ellipticity depends on the coccolith crystal growth which approaches a parallel ellipse (Young, 1989; Young et al., 1996) and, possibly, this leads to less elliptical forms with increasing size. However, we underline that in our study, the long-term morphometric record shows no correspondence between $B$. constans ellipticity and size changes.

Table 1

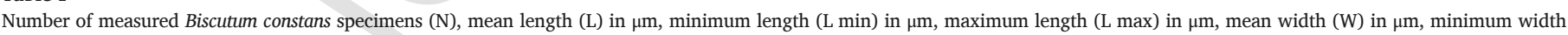
(W min) in $\mu \mathrm{m}$, maximum width (W max) in $\mu \mathrm{m}$, standard deviation (dev.st) and ellipticity for all analysed specimens (Total) and for every established interval.

\begin{tabular}{|c|c|c|c|c|c|c|c|c|c|c|}
\hline & $\mathrm{N}$ & $\mathrm{L}$ & Sdt. dev. & Min L & Max L & $\mathrm{W}$ & Sdt. dev. & Max W & Min W & Ellipticity \\
\hline Total & 2879 & 3.71 & 0.85 & 1.58 & 7.30 & 2.93 & 0.73 & 1.22 & 6.32 & 2.03 \\
\hline Interval 7 & 506 & 3.78 & 0.56 & 2.31 & 6.34 & 3.04 & 0.48 & 1.85 & 5.01 & 1.65 \\
\hline Interval 6 & 405 & 4.19 & 0.74 & 2.66 & 6.35 & 3.42 & 0.62 & 1.65 & 5.31 & 1.76 \\
\hline Interval 5 & 690 & 3.68 & 0.66 & 2.13 & 6.77 & 2.90 & 0.54 & 1.24 & 4.81 & 1.73 \\
\hline Interval 4 & 918 & 3.13 & 0.49 & 1.58 & 5.81 & 2.40 & 0.42 & 1.22 & 4.28 & 1.98 \\
\hline Interval 3 & 120 & 4.80 & 0.89 & 2.15 & 6.73 & 3.81 & 0.79 & 2.03 & 5.55 & 2.03 \\
\hline Interval 2 & 120 & 3.88 & 1.03 & 2.07 & 6.75 & 3.00 & 0.86 & 1.54 & 6.09 & 1.97 \\
\hline Interval 1 & 120 & 5.22 & 1.15 & 2.35 & 7.30 & 4.11 & 1.04 & 1.77 & 6.32 & 1.94 \\
\hline
\end{tabular}




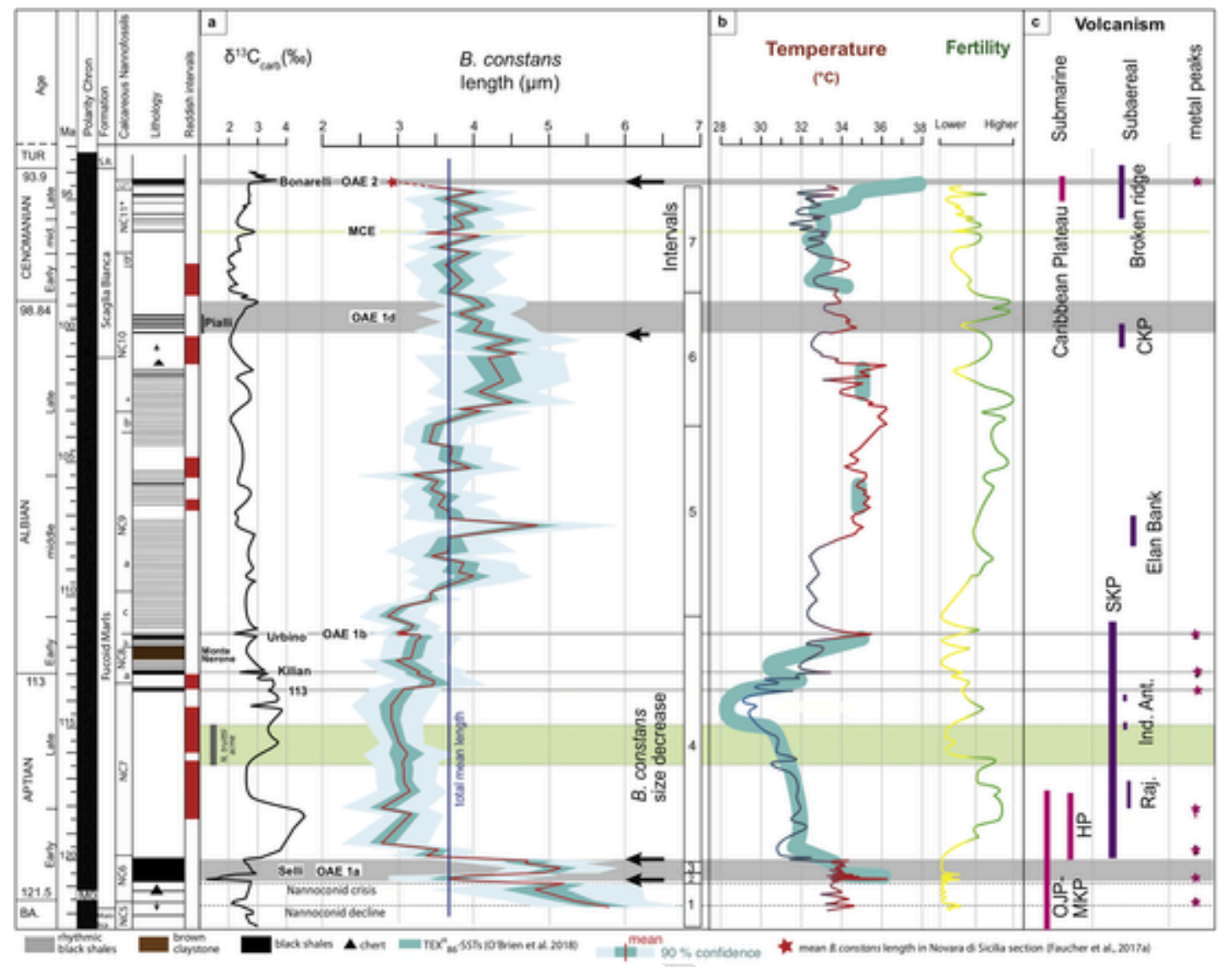

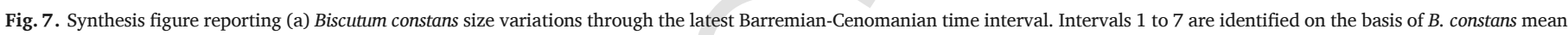

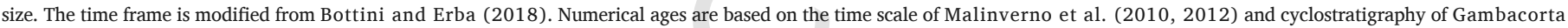

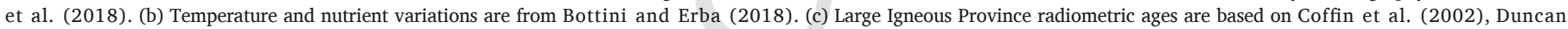

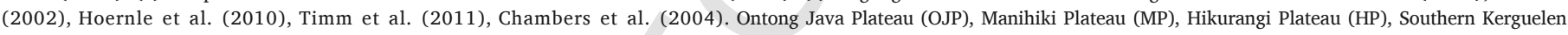
Plateau (SKP), Central Kerguelen Plateau (CKP), Rajmahal Traps (Raj.), Indian Lamprophyre (Ind.), Antarctic Lamprophyre (Ant.). Metal peaks are from Erba et al. (2015).

\subsection{The effects of paleoenvironmental changes on B. constans coccolith size}

The long-term size trends of $B$. constans detected through the studied 28 Myr-long interval can be hardly explained with an evolution pattern towards new subspecies since morphometrics show evidence of one single population and do not display a unique trend towards smaller or larger specimens. Most likely, the size fluctuations that we observe in our study, represent the response to transitory environmental variations which forced this nannoplankton species to adapt (De Vargas et al., 2007).

During the latest Barremian-Cenomanian time interval, the relative abundance of $B$. constans fluctuated in response to changes in surface-water fertility conditions, as discussed in Bottini and Erba (2018) and reference thereinafter, thus it is plausible that surface water fertility also affected the average size of this species. Biscutum constans was a shallow dweller species and preferred mesotrophic conditions (Roth and Krumbach, 1986; Premoli Silva et al., 1989a, 1989b; Watkins, 1989; Coccioni et al., 1992; Erba et al., 1992; Williams and Bralower, 1995; Bellanca et al., 1996; Herrle, 2003; Herrle et al., 2003; Bornemann et al., 2005; Mutterlose et al., 2005; Tremolada et al., 2006; Tiraboschi et al., 2009). Linnert and Mutterlose (2012) and Wulff et al. (2020) proposed a negative effect of low fertility on $B$. constans mean size during the latest Cenomanian-Turonian time interval and the early Barremian Hauptblätterton, respectively. Möller et al. (2020) identified smaller B. constans under elevated nutrient levels across the Valanginian Weissert-OAE. Instead, no correspondence between B. constans size and fertility was evidenced for OAE 1a (Erba et al., 2010), OAE 1d (Bornemann and Mutterlose, 2006) and OAE 2 (Faucher et al., 2017a). Likewise, our dataset shows no correlation with B. constans abundance nor with the NI (Figs. 5 and 7; Supplementary Table S3).

The other main abiotic factor that was postulated to influence calcareous nannofossil size, is the surface-water temperature, that shows large changes during the investigated interval (Fig. 7). Literature data concerning size fluctuations during OAEs, provide different interpretations about the relationship between size changes and temperature: no direct correlation between temperature and $B$. constans size was detected during OAE 1a (Erba et al., 2010) and OAE 2 (Faucher et al., 2017a). Bornemann and Mutterlose (2006) found instead smaller $B$. constans coccoliths under relatively cooler conditions. This contradicts the preference for cool waters of this taxon implied by Lees et al. (2005) and the interpretation proposed by Herrle et al. (2003) that larger Biscutum (B. aff. ellipticum) is a cool-water taxon. Our data do not show a systematic change of temperature and $B$. constans size. Warmer conditions are associated with OAEs and with a prolonged phase (ca. $4 \mathrm{Myr}$ ) in the middle Albian. Coolest temperatures corresponded to the late Aptian and a progressive cooling trend started in the latest Albian. Temperate conditions occurred in the Cenomanian with frequent short-term 
variations (Bottini and Erba, 2018). Despite these climatic fluctuations, no systematic correspondence is detected between temperature and B. constans size (Fig. 7): for e.g., smaller B. constans in the core of OAE 1a was associated with the warmest temperatures. Contrarily, size reduction during interval 4 corresponded to cooler temperatures except for the topmost part of interval 4 marked by a temperature rise not paralleled by size variations. The size increase at the base of interval 5 did not correspond to temperature changes and a significant warming in the middle of the same interval occurred without any B. constans size change. In addition to visual observations, the statistical analyses (Supplementary Table S3) support the absence of correlation between the TI and size.

For extant species, only a limited number of studies analysed coccolith size and shape variations in living coccolithophores under sub-optimal temperature or nutrient conditions. In one of this study, morphological and morphometrical variations of Emiliania huxleyi were observed under SST changes (Watabe and Wilbur, 1966) and an increase in the percentage of aberrant species was hypothesized to be caused by the disturbance of cytoskeleton functionality under sub-optimal temperature (Rosas-Navarro et al., 2016). However, it has not been explained why sub-optimal temperature should disturb cytoskeleton functionality and therefore the intra-cellular production of coccoliths. Moreover, a recent work underlined the lack of a common response among different species towards different temperatures, indicating that coccolithophores do not always produced bigger or smaller coccoliths under sub-optimal temperature values (Faucher et al., 2020). Furthermore, for living coccolithophore, previous authors claimed that coccolith formation, is less adversely affected by nutrient deficiency than growth and cell division (Paasche, 1998): coccoliths continue to be produced under P or $\mathrm{N}$ depletion and, indeed, morphometrical studies did not reveal any drastic variation in size and morphology under nutrient limitation (Faucher et al., 2020). The lack of a direct link between size and temperature variations or nutrient content evidenced in this study for B. constans, and the lack of a common interpretation of temperature and nutrient content effects on B. constans size from other works on Cretaceous intervals, is consistent with data from experiments on living coccolithophores and evidence a strong uncertainty of correlating nutrient and temperature with size fluctuations.

Other paleoenvironmental conditions might have controlled $B$. constans size in the Cretaceous. Different authors suggested that OA induced by $\mathrm{CO}_{2}$ excess (Erba et al., 2010), light deficiency (Lübke et al., 2015; Lübke and Mutterlose, 2016), or combined $\mathrm{CO}_{2}$-excess and higher hydrothermal metal concentrations (Faucher et al., 2017a), were the possible causes of the coccoliths size decrease during OAE 1a and OAE 2. Indeed, OAE $1 \mathrm{a}$ and OAE 2 have in common to have been characterized by intense volcanism associated with Large Igneous Provinces (LIP)s (Fig. 7). The large magmatic-tectonic activity of Manihiki-Ontong Java Plateau (OJP) was responsible for excess $\mathrm{CO}_{2}$ emissions in the ocean-atmosphere system (e.g., Larson and Erba, 1999; Erba and Tremolada, 2004; Heimhofer et al., 2004; Méhay et al., 2009; Tejada et al., 2009; Erba et al., 2010;Kuroda et al., 2011 ; Bottini et al., 2012) and for trace metals input (Erba et al., 2015) which, together with increased weathering rates under greenhouse conditions (e.g., Hochuli et al., 1999; Jenkyns, 2003; Price, 2003; Ando et al., 2008; Keller et al., 2011; Hu et al., 2012; Mutterlose et al., 2014; Bottini et al., 2015), promoted surface water fertility (Bottini et al., 2015) and OA during OAE 1a. Similarly, during OAE 2 the Caribbean Plateau (e.g., Sinton and Duncan, 1997; Turgeon and Creaser, 2008; Du Vivier et al., 2014) was responsible for volcanogenic $\mathrm{CO}_{2}$ injection (Barclay et al., 2010), trace metals release (Snow et al., 2005) and warmer temperatures (Forster et al., 2007). The size variations detected during OAE $1 \mathrm{a}$ and OAE 2 may therefore, represent the response of $B$. constans to a combination of OA, toxic metals and extreme warmth. The same interpretation cannot be proposed for interval 4 since the possibility that OA was sustained for 9 Myrs is unrealistic. Moreover, interval 4 mostly coincided with a marked cooling (McAnena et al., 2013; Bottini et al., 2015) and variable surface water fertility (Fig. 7), thus differing from OAE 1a and OAE 2. Interval 4 is probably the result of an interplay of changing paleoenvironmental conditions which forced $B$. constans to smaller size. The termination of OAE 1a and the onset of interval 4 coincided with the beginning of a cooler phase and with the submarine volcanism of the Hikurangi Plateau and Southern Kerguelen Plateau (SKP) (Duncan, 2002). Possibly, cooler conditions promoted volcanogenic $\mathrm{CO}_{2}$ adsorption leading to temporary acid surface waters. Moreover, LIPs activity was responsible for metal enrichments documented in the Umbria-Marche Basin (in the same section studied here, the Piobbico core) and in other oceanic settings (Erba et al., 2015; Sabatino et al., 2015) suggestive of a global effect of the LIPs volcanism on the chemical composition of oceanic waters. We may assume that toxic elements further influenced $B$. constants inducing a response which is similar to some extant species exposed to higher concentrations of metals (Faucher et al., 2017b). The continuation of interval 4, corresponded to the coolest temperature of the studied interval. As discussed above, temperature alone probably did not control coccolith size decrease. To date, only Bornemann and Mutterlose (2006) and Möller et al. (2020) identified smaller B. constans under cooler temperatures whereas in the other studied intervals, $B$. constans size reduction occurred under warmer conditions (Erba et al., 2010; Lübke et al., 2015; Lübke and Mutterlose, 2016; Linnert and Mutterlose, 2012; Faucher et al., 2017a; Wulff et al., 2020). We speculate that in the early late Aptian-early Albian time interval, temperature exerted an indirect role in forcing the production of small $B$. constans coccoliths, as proposed as follows.

The radiometric ages provided for the SKP suggest that this LIP activity covered from $119 \mathrm{Ma}$ until ca. $110 \mathrm{Ma}$ with prevailing subaerial degassing (Duncan, 2002; Coffin et al., 2002). Although it must be considered that radiometric dates have large uncertainties as do absolute ages in time scales, peaks in abundance of metals detected in the Umbria-Marche Basin and in different settings in the late Aptian-early Albian, have been directly correlated with the SKP (Erba et al., 2015; Sabatino et al., 2015) and correspond to interval 4. The SKP volcanism was subaerial, thus of different impact on the climate and oceanic masses compared to the submarine LIPs. Intense subaerial volcanism may introduce large quantities of sulfur dioxide which alter the atmospheric chemistry (Frey et al., 2003). One possibility is that due to the high latitude at which the SKP plateau formed, the effects of sulfur emissions were amplified, sulfur dioxide and the volatiles were transported into the stratosphere, where they have a longer residence time and great global dispersal, thereby resulting in a relative cooling (Frey et al., 2003). The combination of higher $\mathrm{CO}_{2}$ sequestration in cooler surface waters, and eventually acid rain induced by sulfur emissions, sustained phases of OA across the early Aptian-early Albian time interval. This interpretation is speculative as it should be extended to other oceanic basin records to build a comprehensive model.

We may assume that during the early late Aptian-early Albian time interval, paleoclimatic-paleoenvironmental conditions were not favorable for calcification for a combination of factors which include OA, cooler temperatures and higher trace metal content. The calcareous nannofossil record shows that the nannoplankton displayed a recovery in abundance after the perturbation of OAE 1a, but the maximum carbonate production was only temporary reached during the Nannoconus truittii acme interval and never returned to pre-OAE 1a values (e.g., Herrle and Mutterlose, 2003; Erba and Tremo- 
lada, 2004; Erba et al., 2015). Carbonate platforms were also slowly recovering after OAE 1a (e.g., Weissert et al., 1998; Herrle and Mutterlose, 2003; Föllmi, 2012) possibly affected by cooler climate and waiting for ideal conditions for calcification. Higher total nannoplankton abundance was reached again during the Albian when large and abundant $B$. constans occurred in different ocean basins. This phase coincided with temporary quiescence of volcanism, humid climate and relatively higher nutrients which probably promoted nannoplankton proliferation and calcification (Fig. 7). The next major decline in B. constans size occurred during OAE 2 (Fig. 7).

The analysis of the data suggests that, $B$. constans size followed subsequent and gradual size increases and decreases through the studied $28 \mathrm{Myrs}$ as a strategy to adapt to changing paleoenvironmental conditions. Our results suggest that after environmental condition changes, $B$. constans took advantage of the new ecological state with the production of small coccoliths and the average size did not change for millions of years. Once paleoenvironmental conditions varied again in the middle and late Albian, the abundance of bigger coccoliths progressively increased. The exceptions are the Cretaceous OAEs, when $B$. constans was forced to react in relatively short time to face strong and abrupt perturbations of the ocean-atmosphere system. Indeed, OAEs induced an acute reaction in the calcareous nannoplankton communities, causing the production of dwarf $B$. constans coccoliths for relative short periods of time (hundreds kyrs).

\section{Conclusions}

The long-term morphometric record through the latest Barremian-Cenomanian time interval revealed that in the western Tethys, $B$. constans underwent important size variations which occurred either during OAEs and non-OAE intervals. Most notable is the size decrease detected during OAE 1a, soon after OAE 1a and during OAE 2. One of the most striking results is the 9 Myr-long interval of small coccolith observed from the end of OAE 1a to the early Albian. Larger and abundant specimens of $B$. constans coincided with the late Albian. The widespread extent of this interval of larger $B$. constans possibly makes it a marker for the identification of the lower part of nannofossil subzone NC10a. Minor changes towards smaller $B$. constans were detected during OAE $1 \mathrm{~d}$ and testify a supra-regional significance of this size variation being also detected in the Vocontian Basin.

Paleoclimatic and paleoceanographic proxy data does not support a link between temperature and fertility changes and $B$. constans size variations. The major oceanic perturbation associated with submarine LIPs activity was probably at the base of the size reduction during OAE 1a and OAE 2. The long-lasting phase of small B. constans in the late early Aptian-early Albian time interval represented instead the adaptation to cooler conditions which possibly promoted $\mathrm{CO}_{2}$ sequestration in cooler surface waters. In addition, pulses of subaerial volcanism of the SKP may have further affected the ocean chemistry forcing $B$. constans to produce small coccoliths. The record shows that $B$. constans was able to adapt and take advantage of new ecological states.

\section{Declaration of Competing Interest}

The authors declare that they have no known competing financial interests or personal relationships that could have appeared to influence the work reported in this paper.

\section{Acknowledgements}

We thank two anonymous reviewers and the editor Isabel Montanez for greatly improving the article. We would like to thank Elisa- betta Erba for support and valuable discussions. This research was funded through SIR-2014 (Ministero dell'Istruzione, dell'Università e della Ricerca-Scientific Independence of young researchers) to Cinzia Bottini (grant no. SIR-2014 RBSI14UU81) and PRIN 2017RX9XXXY.

\section{Appendix A. Supplementary data}

Supplementary data to this article can be found online at https://doi. org/10.1016/j.palaeo.2020.109852.

\section{References}

Alvarez, W, Lowrie, W, 1984. Magnetic stratigraphy applied to synsedimentary slumps, turbidites, and basin analysis; the Scaglia Limestone at Furlo (Italy). Geol. Soc. Am. Bull. 95 (3), 324-336.

Ando, A, Kaiho, K, Kawahata, H, Kakegawa, T, 2008. Timing and magnitude of early Aptian extreme warming: unraveling primary ${ }^{18} \mathrm{O}$ variation in indurated pelagic carbonates at Deep Sea Drilling Project Site 463, central Pacific Ocean. Palaeogeogr. Palaeoclimatol. Palaeoecol. 260, 463-476. doi:10.1016/j.palaeo.2007.12.007.

Barbarin, N, Bonin, A, Mattioli, E, Pucéat, E, Cappetta, H, Gréselle, B, Pittet, B, Vennin, E, Joachimski, M, 2012. Evidence for a complex Valanginian nannoconid decline in the Vocontian basin (South East France). Mar. Micropaleontol. 84, 37-53. doi:10.1016/ j.marmicro.2011.11.005.

Barclay, R S, McElwain, J C, Sageman, B B, 2010. Carbon sequestration activated by a volcanic $\mathrm{CO}_{2}$ pulse during Ocean Anoxic Event 2. Nat. Geosci. 3 (3), 205-208. doi:10.1038/ngeo757.

Bellanca, A, Claps, M, Erba, E, Masetti, D, Neri, R, Premoli Silva, I, Venezia, F, 1996. Orbitally induced limestone/marlstone rhythms in the Albian-Cenomanian Cismon section (Venetian region, northern Italy): sedimentology, calcareous and siliceous plankton distribution, elemental and isotope geochemistry. Palaeogeogr. Palaeoclimatol. Palaeoecol. 126, 227-260. doi:10.1016/S0031-0182(96)00041-7.

Bernoulli, D, 1972. North Atlantic and Mediterranean Mesozoic facies: a comparison. In: Initial Reports of the Deep Sea Drilling Project, 11. pp. 801-871.

Bernoulli, D, Jenkyns, H C, 1974. Alpine, Mediterranean, and Central Atlantic Mesozoic facies in relation to the early evolution of the Tethys. In: Dott, R H, Shaver, R H (Eds.), Modern and Ancient Geosynclinal Sedimentation, Special Publication, 19. Soc. Econ. Paleontologists Mineralogists, Tulsa, Okla, pp. 129-160.

Bernoulli, D, Jenkyns, H C, 2009. Ancient oceans and continental margins of the Alpine-Mediterranean Tethys: deciphering clues from Mesozoic pelagic sediments and ophiolites. Sedimentology 56, 149-190. doi:10.1111/j.1365-3091.2008.01017.x.

Black, M, 1967. New names for some coccolith taxa. Proc. Geol. Soc. Lond. 1640, 139-145.

Bornemann, A, Mutterlose, J, 2006. Size analyses of the coccolith species Biscutum constans and Watznaueria barnesiae from the Late Albian "Niveau Breistroffer" (SE France): taxonomic and palaeoecological implications. Geobios 39 (5), 599-615. doi:10.1016/ j.geobios.2005.05.005.

Bornemann, A, Pross, J, Reichelt, K, Herrle, J O, Hemleben, C, Mutterlose, J, 2005. Reconstruction of short term palaeoceanographic changes during the formation of the Late Albian-Niveau Breistroffer- black shales (Oceanic Anoxic Event 1d, SE France). J. Geol. Soc. 623-639. doi:10.1144/0016-764903-171162.

Bottini, C, Erba, E, 2018. Mid-Cretaceous paleoenvironmental changes in the western Tethys. Clim. Past 14, 1147-1163. doi:10.5194/cp-14-1147-2018.

Bottini, C, Cohen, A S, Erba, E, Jenkyns, H C, Coe, A L, 2012. Osmium-isotope evidence for volcanism, weathering, and ocean mixing during the early Aptian OAE 1a. Geology 40 (7), 583-586. doi:10.1130/G33140.1.

Bottini, C, Erba, E, Tiraboschi, D, Jenkyns, H C, Schouten, S, Sinninghe Damsté, J S, 2015 Climate variability and ocean fertility during the Aptian Stage. Clim. Past 11 (3). doi:10.5194/cp-11-383-2015.

Bown, P R, Young, J R, 1998. Introduction. In: Bown, P R (Ed.), Calcareous Nannofossil Biostratigraphy. British Micropalentol. Soc. Publ. Series, Kluver Academic Publ. University Press, Cambridge, UK, pp. 1-15.

Bown, P R, Lees, J A, Young, J R, 2004. Calcareous nannoplankton evolution and diversity through time. In: Coccolithophores. Springer Berlin Heidelberg, pp. 481-508.

Brace, B J, Watkins, D K, 2014. Evolution of the calcareous nannofossil genus Biscutum in the middle to Upper Cretaceous North American mid-latitudes. Micropaleontology 445-463.

Bralower, T J, Leckie, R M, Sliter, W V, Thierstein, H R, 1995. An integrated Cretaceous microfossil biostratigraphy. In: Berggren, W A, Kent, D V, Aubry, M P, Hardenbol, J (Eds.), Geochronology Time Scales and Global Stratigraphic Correlation. In: Geochronology, Time Scales, and Global Stratigraphic Correlation, Spec. Publ.-SEPM (Soc. Sediment. Geol.), 54. pp. 65-79.

Čepek, P, 2001. Calcareous nannoplankton from the 'Boreal' Late Albian of NW Germany (Kirchrode I borehole): its biostratigraphy and cyclicity. Palaeogeogr. Palaeoclimatol. Palaeoecol. 174 (1-3), 181-197. doi:10.1016/S0031-0182(01)00293-0.

Chambers, L M, Pringle, M S, Fitton, J G, 2004. Phreatomagmatic eruptions on the Ontong Java Plateau: an Aptian 40Ar/39Ar age for volcaniclastic rocks at ODP Site 1184. In: Fitton, J G, Mahoney, J J, Wallace, P J, Saunders, A D (Eds.), 
Origin and Evolution of the Ontong Java Plateau: Geological Society of London Special Publication, 229. pp. 325-331. doi:10.1144/GSL.SP.2004.229.01.18.

Coccioni, R, Galeotti, S, 2003. The mid-Cenomanian Event: prelude to OAE 2. Palaeogeogr. Palaeoclimatol. Palaeoecol. 190, 427-440. doi:10.1016/S0031-0182(02)00617-X.

Coccioni, R, Erba, E, Premoli Silva, I, 1992. Barremian-Aptian calcareous plankton biostratigraphy from the Gorgo a Cerbara section (Marche, Central Italy) and implication for planktonic evolution. Cretac. Res. 13, 517-537. doi:10.1016/ 0195-6671(92)90015-I.

Coffin, M F, Pringle, M S, Duncan, R A, Gladczenko, T P, Storey, M, Müller, R D, Gahagan, L A, 2002. Kerguelen hotspot magma output since 130 Ma. J. Petrol. 43, 1121-1137. doi:10.1093/petrology/43.7.1121.

Danelian, T, Baudin, F, Gardin, S, Masure, E, Ricordel, C, Fili, I, Meçaj, T, Muska, K, 2007. The record of mid Cretaceous oceanic anoxic events from the Ionian zone of southern Albania. Rev. Micropaleontol. 50 (3), 225-237.

De Vargas, C, Aubry, M P, Probert, I A N, Young, J, 2007. Origin and evolution of coccolithophores: from coastal hunters to oceanic farmers. In: Evolution of Primary Producers in the Sea. Academic Press, pp. 251-285.

Du Vivier, A D, Selby, D, Sageman, B B, Jarvis, I, Gröcke, D R, Voigt, S, 2014. Marine ${ }^{187} \mathrm{Os} /{ }^{188}$ Os isotope stratigraphy reveals the interaction of volcanism and ocean circulation during Oceanic Anoxic Event 2. Earth Planet. Sci. Lett. 389, 23-33. doi:10.1016/j.epsl.2013.12.024.

Duncan, R A, 2002. A time for construction of the Kerguelen Plateau and Broken Ridge. J. Petrol. 43, 1109-1119. doi:10.1093/petrology/43.7.1109.

Erba, E, 1988. Aptian-Albian calcareous nannofossil biostratigraphy of the Scisti a Fucoidi cored at Piobbico (central Italy). Riv. Ital. Paleontol. Stratigr. 94, 249-284.

Erba, E, 1992. Middle Cretaceous calcareous nannofossils from the Western Pacific (ODP Leg 129): evidence for paleoequatorial crossings. In: Larson, R L, Lancelot, Y (Eds.), Proceedings of the Ocean Drilling Program, Scientific Results, 129. pp. 189-201.

Erba, E, 2006. The first 150 million years history of calcareous nannoplankton: biosphere-geosphere interactions. Palaeogeogr. Palaeoclimatol. Palaeoecol. 232 (2), 237-250. doi:10.1016/j.palaeo.2005.09.013.

Erba, E, Premoli Silva, I, 1994. Orbitally driven cycles in trace-fossil distribution from the Piobbico core (late Albian, central Italy). In: Orbital Forcing and Cyclic Sequences, 19. International Association of Sedimentologists, pp. 211-225.

Erba, E, Tremolada, F, 2004. Nannofossil carbonate fluxes during the Early Cretaceous: Phytoplankton response to nutrification episodes, atmospheric $\mathrm{CO}_{2}$, and anoxia. Paleoceanogr. Paleoclimatol. 19 (1). doi:10.1029/2003PA000884.

Erba, E, Channell, J E T, Claps, M, Jones, C, Larson, R, Bradley, O, Premoli Silva, I, Riva, A, Salvini, G, Torricelli, S, 1999. Integrated stratigraphy of the Cismon Apticore (southern Alps, Italy); a "reference section" for the Barremian-Aptian interval at low latitudes. J. Foramin. Res. 29(4), 371-391.

Erba, E, Coccioni, R, Premoli Silva, I, 1989. Gli Scisti a Fucoidi nell'area umbro-marchigiana: le sezioni della S.S. Apecchiese. In: Cresta, S, Monechi, S, Parisi, G (Eds.), Stratigrafia del Mesozoico e Cenozoico nell'area umbro-marchigiana. Itinerari geologici sull'Appennino umbro marchigiano (Italia). Memorie Descrittive della Carta Geologica d'Italia 39. Istituto Poligrafico e Zecca dello Stato, Roma, pp. 146-164.

Erba, E, Castradori, D, Guasti, G, Ripepe, M, 1992. Calcareous nannofossils and Milankovitch cycles: the example of the Albian Gault Clay Formation (southern England). Palaeogeogr. Palaeoclimatol. Palaeoecol. 93 (1), 47-69. doi:10.1016/ 0031-0182(92)90183-6f

Erba, E, Bottini, C, Weissert, H J, Keller, C E, 2010. Calcareous nannoplankton response to surface-water acidification around Oceanic Anoxic Event 1a. Science 329 (5990), 428-432. doi:10.1126/science.1188886.

Erba, E, Duncan, R A, Bottini, C, Tiraboschi, D, Weissert, H, Jenkyns, H C, Malinverno, A, 2015. Environmental Consequences of Ontong Java Plateau and Kerguelen Plateau Volcanism. GSA Special Paper 511. doi:10.1130/2015.2511.

Erba, E, Bottini, C, Faucher, G, Gambacorta, G, Visentin, S, 2019. The response of calcareous nannoplankton to Oceanic Anoxic events: the Italian pelagic record. Boll. Soc. Paleontol. Italiana 58 (1), 51-71.

Faucher, G, Erba, E, Bottini, C, Gambacorta, G, 2017. Calcareous nannoplankton response to the latest Cenomanian Oceanic Anoxic Event 2 perturbation. Riv. Italiana Paleontol. Stratigr. 123, 159-176 (/2039-4942/8092).

Faucher, G, Hoffmann, L, Bach, L T, Bottini, C, Erba, E, Riebesell, U, 2017. Impact of trace metal concentrations on coccolithophore growth and morphology: laboratory simulations of Cretaceous stress. Biogeosciences 14, 3603-3613. doi:10.5194/ bg-14-3603-2017.

Faucher, G, Riebesell, U, Bach, L T, 2020. Can morphological features of coccolithophores serve as a reliable proxy to reconstruct environmental conditions of the past? Clim. Past (in press).

Ferreira, J, Mattioli, E, van de Schootbrugge, B, 2017. Palaeoenvironmental vs. evolutionary control on size variation of coccoliths across the Lower-Middle Jurassic? Palaeogeogr. Palaeoclimatol. Palaeoecol. 465, 177-192. doi:10.1016/ j.palaeo.2016.10.029.

Fiet, N, Beaudoin, B, Parize, O, 2001. Lithostratigraphic analysis of Milankovitch cyclicity in pelagic Albian deposits of central Italy: implications for the duration of the stage and substages. Cretac. Res. 22, 265-275.

Fisher, A G, Herbert, T D, Napoleone, G, Premoli Silva, I, Ripepe, M, 1991. Albian pelagic rhythms (Piobbico Core). J. Sediment. Petrol. 61, 1164-1172.

Föllmi, K B, 2012. Early Cretaceous life, climate and anoxia. Cretac. Res. 35, 230-257. doi:10.1016/j.cretres.2011.12.005.

Forster, A, Schouten, S, Moriya, K, Wilson, P A, Sinninghe Damsté, J S, 2007. Tropical warming and intermittent cooling during the Cenomanian/Turonian oceanic anoxic event 2: sea surface temperature records from the equatorial Atlantic. Paleoceanogr. Paleoclimatol. 22 (1). doi:10.1029/2006PA001349.
Frey, F A, Coffin, M F, Wallace, P J, Quilty, P J, 2003. Proceedings of the Ocean Drilling Program, Scientific Results. 183. Ocean Drilling Program, College Station, Texas. doi:10.2973/odp.proc.sr.183.2003.

Gambacorta, G, Bersezio, R, Erba, E, 2014. Sedimentation in the Tethyan pelagic realm during the Cenomanian: monotonous settling or active redistribution? Palaeogeogr. Palaeoclimatol. Palaeoecol. 409, 301-319.

Gambacorta, G, Jenkyns, H C, Russo, F, Tsikos, H, Wilson, P A, Faucher, G, Erba, E, 2015 Carbon-and oxygen-isotope records of mid-Cretaceous Tethyan pelagic sequences from the Umbria-Marche and Belluno Basins (Italy). Newsl. Stratigr. 48 (3), 299-323. doi:10.1127/nos/2015/0066.

Gambacorta, G, Bersezio, R, Weissert, H, Erba, E, 2016. Onset and demise of Cretaceous oceanic anoxic events: the coupling of surface and bottom oceanic processes in two pelagic basins of the western Tethys. Paleoceanogr. Paleoclimatol. 31, 732-757. doi:10.1002/2015PA002922.

Gambacorta, G, Malinverno, A, Erba, E, 2018. Orbital forcing of carbonate versus siliceous productivity in the late Albian-late Cenomanian (Umbria-Marche Basin, central Italy). Newslett. Stratigr. 52 (2), 197-220 2019.

Giorgioni, M, Weissert, H, Bernasconi, S M, Hochuli, P A, Coccioni, R, Keller, C E, 2012. Orbital control on carbon cycle and oceanography in the mid-Cretaceous greenhouse. Paleoceanogr. Paleoclimatol. 27, PA1204. doi:10.1029/2011PA002163.

Giraud, F, Pittet, B, Mattioli, E, Audouin, V, 2006. Paleoenvironmental controls on the morphology and abundance of the coccolith Watznaueria britannica (Late Jurassic, southern Germany). Mar. Micropaleontol. 60 (3), 205-225. doi:10.1016/ j.marmicro.2006.04.004.

Gollain, B, Mattioli, E, Kenjo, S, Bartolini, A, Reboulet, S, 2019. Size patterns of the coccolith Watznaueria barnesiae in the lower Cretaceous: Biotic versus abiotic forcing. Mar. Micropaleontol. 152, 101740. doi:10.1016/j.marmicro.2019.03.012.

Górka, H, 1957. Les Coccolithophoridés du Maestrichtien supérieur de Pologne. Acta Palaeontol. Pol. 2, 239-284.

Grippo, A, Fischer, A G, Hinnov, L A, Herbert, T D, Premoli Silva, I, 2004. Cyclostratigraphy and chronology of the Albian stage (Piobbico core, Italy). In: D'Argenio, B, Fischer, A G, Premoli Silva, I, Weissert, H, Ferreri, V (Eds.), Cyclostratigraphy: Approaches and Case Histories. Society for Sedimentary Geology Special Publication 81. Tulsa, Oklahoma. pp. 57-81.

Grün, W, Allemann, F, 1975. The Lower Cretaceous of Caravaca (Spain). Berriasian calcareous nannoplankton of the Miravetes Section (Subbetic Zone, Prov. of Murcia). Eclogae Geol. Helv. 68, 147-211.

Hammer, $\varnothing$, Harper, D A T, Ryan, P D, 2001. PAST: paleontological statistics software package for education and data analysis. Palaeontol. Electron. 4, 1-9.

Heimhofer, U, Hochuli, P A, Herrle, J O, Andersen, N, Weissert, H, 2004. Absence of major vegetation and palaeoatmospheric $\mathrm{pCO}_{2}$ changes associated with oceanic anoxic event 1a (Early Aptian, SE France). Earth Planet. Sci. Lett. 223, 303-318. doi:10.1016/ j.epsl.2004.04.037.

Henderiks, J, 2008. Coccolithophore size rules-reconstructing ancient cell geometry and cellular calcite quota from fossil coccoliths. Mar. Micropaleontol. 67 (1), 143-154. doi:10.1016/j.marmicro.2008.01.005.

Hennhoefer, D, Al Suwaidi, A, Bottini, C, Helja, E, Steuber, T, 2019. The Albian to Turonian carbon isotope record from the Shilaif Basin (United Arab Emirates) and its regional and intercontinental correlation. Sedimentology 66 (2), 536-555.

Herbert, T D, Fischer, A G, 1986. Milankovitch climatic origin of mid-Cretaceous black shale rhythms in central Italy. Nature 321, 739-743.

Herbert, T, Premoli Silva, I, Erba, E, Fischer, A G, 1995. Orbital chronology of Cretaceous-Paleocene marine sediments. In: Berggren, W A, Kent, D V, Aubry, M P, Hardenbol, J (Eds.), Geochronology, Time Scales, and Global Stratigraphic Correlation: SEPM (Society for Sedimentary Geology) Special Publication, 54. pp. 81-93. doi:10.2110/pec.95.04.0081.

Herrle, J O, 2003. Reconstructing nutricline dynamics of mid-Cretaceous oceans: evidence from calcareous nannofossils from the Niveau Paquier black shale (SE France). Mar. Micropaleontol. 47, 307-321. doi:10.1016/S0377-8398(02)00133-0.

Herrle, J O, Mutterlose, J, 2003. Calcareous nannofossils from the Aptian-Lower Albian southeast France: paleoecological and biostratigraphic implication. Cretac. Res. 24, 1-22. doi:10.1016/S0195-6671(03)00023-5.

Herrle, J O, Pross, J, Friedrich, O, Kössler, P, Hemleben, C, 2003. Forcing mechanisms for Mid-Cretaceous black shale formation: evidence from the upper Aptian and lower Albian of the Vocontian Basin (SE France). Palaeogeogr. Palaeoclimatol. Palaeoecol. 190, 399-426. doi:10.1016/S0031-0182(02)00616-8.

Hochuli, P A, Menegatti, A P, Weissert, H, Riva, A, Erba, E, Premoli Silva, I, 1999. Episodes of high productivity and cooling in the early Aptian Alpine Tethys. Geology 27, 657-660. doi:10.1130/0091-7613(1999)027<0657:EOHPAC > 2.3.CO;2.

Hoernle, K, Hauff, F, van den Bogaard, P, Werner, R, Mortimer, N, Geldmacher, J, Garbe-Schönberg, D, Davy, B, 2010. Age and geochemistry of volcanic rocks from the Hikurangi and Manihiki oceanic Plateaus. Geochim. Cosmochim. Acta 74, 7196-7219 v. doi:10.1016/j.gca.2010.09.030.

$\mathrm{Hu}$, X, Kuidong, Z, Yilmaz, I O, Yongxiang, L, 2012. Stratigraphic transition and palaeoenvironmental changes from the Aptian oceanic anoxic event 1a (OAE1a) to the oceanic red bed 1 (ORB1) in the Yenicesihlar section, central Turkey. Cretac. Res. 38, 40-51. doi:10.1016/j.cretres.2012.01.007.

Jenkyns, H C, 2003. Evidence for rapid climate change in the Mesozoic-Palaeogene greenhouse world. Philos. Trans. R. Soc. Lond. A 361 (1810), 1885-1916.

Keller, C E, Hochuli, P A, Weissert, H, Weissert, H, Bernasconi, S M, Giorgioni, M, Garcia, T I, 2011. A volcanically induced climate warming and floral change preceded the onset of OAE1a (Early Cretaceous). Palaeogeogr. Palaeoclimatol. Palaeoecol. 305, 43-49. doi:10.1016/j.palaeo.2011.02.011. 
Kuroda, J, Tanimizu, M, Hori, R S, Suzuki, K, Ogawa, N O, Tejada, M L G, Coccioni, $\mathrm{R}$, Erba, E, Ohkouchi, N, 2011. Lead isotopic record of Barremian-Aptian marine sediments: Implications for large igneous provinces and the Aptian climatic crisis. Earth Planet. Sci. Lett. 307 (1-2), 126-134. doi:10.1016/j.epsl.2011.04.021.

Larson, R L, Erba, E, 1999. Onset of the Mid-Cretaceous greenhouse in the Barremian-Aptian: igneous events and the biological, sedimentary, and geochemical responses. Paleoceanogr. Paleoclimatol. 14 (6), 663-678. doi:10.1029/ 1999PA900040.

Lees, J A, Bown, P R, Mattioli, E, 2005. Problems with proxies? Cautionary tales of calcareous nannofossil paleoenvironmental indicators. Micropaleontology 51, 333-343. doi:10.2113/gsmicropal.51.4.333.

Linnert, C, Mutterlose, J, 2012. Biometry of Cenomanian-Turonian placoliths: a proxy for changes of fertility and surface-water temperature? Lethaia 46 (1), 82-97. doi:10.1111/j.1502-3931.2012.00323.x

Lübke, N, Mutterlose, J, 2016. The impact of OAE 1a on marine biota deciphered by size variations of coccoliths. Cretac. Res. 61, 169-179. doi:10.1016/j.cretres.2016.01.006.

Lübke, N, Mutterlose, J, Bottini, C, 2015. Size variations of coccoliths in Cretaceous oceans - a result of preservation, genetics and ecology? Mar. Micropaleontol. 117, 25-39. doi:10.1016/j.marmicro.2015.03.002.

Malinverno, A, Erba, E, Herbert, T D, 2010. Orbital tuning as an inverse problem: chronology of the early Aptian oceanic anoxic event 1a (Selli Level) in the Cismon Apticore. Paleoceanogr. Paleoclimatol. 25, PA2203. doi:10.1029/2009PA001769.

Malinverno, A, Hildebrandt, J, Tominaga, M, Channell, J E T, 2012. M-sequence geomagnetic polarity time scale (MHTC12) that steadies global spreading rates and incorporates astrochronology constraints. J. Geophys. Res. 117, B06104. doi:10.1029/ 2012JB009260.

Mattioli, E, Pittet, B, Young, J R, Bown, P R, 2004. Biometric analysis of Pliensbachian-Toarcian (Lower Jurassic) coccoliths of the family Biscutaceae: intraand interspecific variability versus palaeoenvironmental influence. Mar. Micropaleontol. 52, 5-27. doi:10.1016/j.marmicro.2004.04.004.

Mattioli, E, Pittet, B, Petitpierre, L, Mailliot, S, 2009. Dramatic decrease of pelagic carbonate production by nannoplankton across the early Toarcian anoxic event (T-OAE). Global Planet. Change 65, 134-145. doi:10.1016/j.gloplacha.2008.10.018.

McAnena, A, Flögel, S, Hofmann, P, Herrle, J O, Griesand, A, Pross, J, Talbot, H M, Rethemeyer, J, Wallmann, K, Wagner, T, 2013. Atlantic cooling associated with a marine biotic crisis during the mid-Cretaceous period. Nat. Geosci. 6, 558-651. doi:10.1038/ngeo1850.

Méhay, S, Keller, C E, Bernasconi, S M, Weissert, H, Erba, E, Bottini, C, Hochuli, P A, 2009. A volcanic $\mathrm{CO} 2$ pulse triggered the Cretaceous Oceanic Anoxic Event 1a and a biocalcification crisis. Geology 37 (9), 819-822. doi:10.1130/G30100A.1.

Möller, C, Bornemann, A, Mutterlose, J, 2020. Climate and paleoceanography controlling size variations of calcareous nannofossils during the Valanginian Weissert Event (early cretaceous). Mar. Micropaleontol. 157, 101875. doi:doi.org/10.1016/ j.marmicro.2020.101875.

Mutterlose, J, Bornemann, A, Herrle, J O, 2005. Mesozoic calcareous nannofossils-state of the art. Paläontol. Z. 79 (1), 113-133.

Mutterlose, J, Bottini, C, Schouten, S, Sinninghe Damsté, J S, 2014. High sea-surface temperatures during the early Aptian OAE 1a in the Boreal Realm. Geology 42, 439-442. doi:10.1130/G35394.1.

Paasche, E, 1998. Roles of nitrogen and phosphorus in coccolith formation in Emiliania huxleyi (Prymnesiophyceae). Eur. J. Phycol. 33 (1), 33-42. doi:10.1080/ 09670269810001736513.

Peti, L, Thibault, N, 2017. Abundance and size changes in the calcareous nannofossil Schizosphaerella - Relation to sea-level, the carbonate factory and palaeoenvironmental change from the Sinemurian to earliest Toarcian of the Paris Basin. Palaeogeogr. Palaeoclimatol. Palaeoecol. 485, 271-282. doi:10.1016/ j.palaeo.2017.06.019.

Premoli Silva, I, Erba, E, Tornaghi, M E, 1989. Paleoenvironmental signals and changes in surface fertility in mid Cretaceous Corg-rich pelagic facies of the Fucoid Marls (central Italy). Geobios 22, 225-236. doi:10.1016/S0016-6995(89)80059-2.

Premoli Silva, I, Ripepe, M, Tornaghi, M E, 1989. Planktonic foraminiferal distribution record productivity cycles: evidence from the Aptian-Albian Piobbico core (central Italy). Terra Nova 1, 443-448. doi:10.1111/j.1365-3121.1989.tb00407.x.

Price, G D, 2003. New constraints upon isotope variation during the early Cretaceous (Barremian-Cenomanian) from the Pacific Ocean. Geol. Mag. 140, 513-522 (Price).

Rosas-Navarro, A, Langer, G, Ziveri, P, 2016. Temperature affects the morphology and calcification of Emiliania huxleyi strains. Biogeosciences 13 (10), 2913-2926. doi:10.5194/bg-13-2913-2016.

Rosenbaum, G, Lister, G S, Duboz, C, 2004. The Mesozoic and Cenozoic motion of Adria (central Mediterranean): a review of constraints and limitations. Geodin. Acta 17 (2), 125-139. doi:10.3166/ga.17.125-139.
Roth, P H, 1979. Cretaceous calcareous nannoplankton diversity and paleoceanography. In: Proc. IV Int. Palynol. Conf. Lucknow, (1976-77), 2. pp. 22-33.

Roth, P H, 1987. Mesozoic calcareous nannofossil evolution: relation to paleoceanographic events. Paleoceanogr. Paleoclimatol. 2 (6), 601-611.

Roth, P H, 1989. Ocean circulation and calcareous nannoplankton evolution during the Jurassic and Cretaceous. Palaeogeogr. Palaeoclimatol. Palaeoecol. 74 (1), 111-126.

Roth, P H, Bowdler, J L, 1981. Middle Cretaceous calcareous nannoplankton biogeography and graphy of the Atlantic Ocean. SEPM Spec. Publ. 32, 517-546.

Roth, P H, Krumbach, K R, 1986. Middle Cretaceous calcareous nannofossil biogeography and preservation in the Atlantic and Indian Oceans: implications for paleoceanography. Mar. Micropaleontol. 10 (1), 235-266.

Sabatino, N, Coccioni, R, Manta, D S, Baudin, F, Vallefuoco, M, Traina, A, Sprovieri, M, 2015. High-resolution chemostratigraphy of the late Aptian-early Albian oceanic anoxic event (OAE 1b) from the Poggio le Guaine section (Umbria-Marche Basin, central Italy). Palaeogeogr. Palaeoclimatol. Palaeoecol. 426, 319-333. doi:10.1016/ j.palaeo.2015.03.009.

Schwarzacher, W, 1994. Cyclostratigraphy of the Cenomanian in the Gubbio district, Italy: a field study. In: de Boer, P L, Smith, D G (Eds.), Orbital Forcing and Cyclic Sequences. Special Publications International Association of Sedimentologists 19. Tulsa, Oklahoma. pp. 99-107.

Sinton, C W, Duncan, R A, 1997. Potential links between ocean plateau volcanism and global ocean anoxia at the Cenomanian-Turonian boundary. Econ. Geol. Bull. Soc. Econ. Geol. 92, 836-842. doi:10.2113/gsecongeo.92.7-8.836.

Snow, L J, Duncan, R A, Bralower, T J, 2005. Trace element abundances in the Rock Canyon Anticline, Pueblo, Colorado, marine sedimentary section and their relationship to Caribbean plateau construction and oxygen anoxic event 2 . Paleoceanogr. Paleoclimatol. 20, 3. doi:10.1029/2004PA001093.

Tejada, M L G, Suzuki, K, Kuroda, J, Coccioni, R, Mahoney, J, John, J, Ohkouchi, N, Sakamoto, T, Tatsumi, Y, 2009. Ontong Java Plateau eruption as a trigger for the early Aptian oceanic anoxic event. Geology 37 (9), 855-858. doi:10.1130/G25763A.1.

Timm, C, Hoernle, K, Werner, R, Hauff, F, van den Bogaard, P, Michael, P, Coffin, M F, Koppers, A, 2011. Age and geochemistry of the oceanic Manihiki Plateau, SW Pacifi c: new evidence for a plume origin. Earth Planet. Sci. Lett. 304, 135-146. doi:10.1016/ j.epsl.2011.01.025.

Tiraboschi, D, Erba, E, Jenkyns, H J, 2009. Origin of rhythmic Albian black shales (Piobbico core, central Italy) Calcareous nannofossil quantitative and statistical analyses and paleoceanographic reconstructions. Paleoceanogr. Paleoclimatol. 24, PA2222. doi:10.1029/2008PA001670.

Tremolada, F, Erba, E, Bralower, T J, 2006. Late Barremian to Early Aptian calcareous nannofossil paleoceanography and paleoecology from the Ocean Drilling Program Hole 641C (Galicia Margin). Cretac. Res. 27, 887-897. doi:10.1016/ j.cretres.2006.04.007.

Turgeon, S C, Creaser, R A, 2008. Cretaceous oceanic anoxic event 2 triggered by a massive magmatic episode. Nature 454 (7202), 323-326. doi:10.1038/nature07076.

Watabe, N, Wilbur, K M, 1966. Effects of temperature on growth, calcification, and coccolith form in Coccolithus huxleyi (Coccolithineae). Limnol. Oceanogr. 11 (4), 567-575. doi:10.4319/lo.1966.11.4.0567.

Watkins, D K, 1989. Nannoplankton productivity fluctuations and rhythmically-bedded pelagic carbonates of the Greenhorn Limestone (Upper Cretaceous). Palaeogeogr. Palaeoclimatol. Palaeoecol. 74, 75-86.

Weissert, H, Erba, E, 2004. Volcanism, CO2 and palaeoclimate: a Late Jurassic-Early Cretaceous carbon and oxygen isotope record. J. Geol. Soc. 161 (4), 695-702.

Weissert, H, Lini, A, Föllmi, K B, Kuhn, O, 1998. Correlation of Early Cretaceous carbon isotope stratigraphy and platform drowning events: a possible link? Palaeogeogr Palaeoclimatol. Palaeoecol. 137, 189-203.

Williams, J R, Bralower, T J, 1995. Nannofossil assemblage, fine fraction stable isotopes, and the paleoceanography of the Valanginian-Barremian (Early Cretaceous) North Sea Basin. Pale Paleoceanogr. Paleoclimatol. 10, 815-839. doi:10.1029/95PA00977.

Wulff, L, Mutterlose, J, Bornemann, A, 2020. Size variations and abundance patterns of calcareous nannofossils in mid Barremian black shales of the Boreal Realm (Lower Saxony Basin). Mar. Micropaleontol. 156, 101853. doi:doi.org/10.1016/ j.marmicro.2020.101853.

Young, J R, 1989. Observations on heterococcolith rim structure and its relationship to developmental processes. In: Crux, J A, van Heck, S E (Eds.), Nannofossils and Their Applications. Ellis Horwood, Chichester, pp. 1-20.

Young, J R, Kucera, M, Chung, H W, 1996. Automated biometrics on capturd light microscope images of coccoliths of Emiliania huxleyi. In: Moguilewski, A, Whatley, R (Eds.), Microfossils and Oceanic Environments. Aberystwyth Press, Aberystwyth, pp. 261-277. 